\title{
Falling Weight Deflectometer Analysis of Low Volume Roads
}

\author{
Shrikant Madhav Harle ${ }^{1,}$, Prakash Pajgade ${ }^{2}$ \\ ${ }^{1}$ Department of Civil Engineering, Prof Ram Meghe College of Engineering \& Management, Badnera, India \\ ${ }^{2}$ Department of Civil Engineering, Prof Ram Meghe Institute of Technology \& Research, Badnera, India
}

Email address:

shrikantharle@gmail.com (S. M. Harle)

${ }^{*}$ Corresponding author

\section{To cite this article:}

Shrikant Madhav Harle, Prakash Pajgade. Falling Weight Deflectometer Analysis of Low Volume Roads. Journal of Civil, Construction and Environmental Engineering. Special Issue: Computational Technologies in Concrete Structures. Vol. 4, No. 4, 2019 , pp. 73-80. doi: $10.11648 /$ j.jccee.20190404.11

Received: June 14, 2019; Accepted: September 16, 2019; Published: September 23, 2019

\begin{abstract}
The work was carried out on the village roads where the traffic intensity is very low. The roads should be constructed as durable and with minimum construction cost without affecting the strength. Therefore the experiments were carried out on different types of roads. The experiments can be performed in the laboratory but that is not sufficient and therefore the tests should also be performed on the actual constructed pavement patches. The non destructive test is the best way to check the parameters responsible for the effectiveness of pavement. The non destructive testing machines like ground penetrating radar (GPR) and falling weight deflectometer is used to assess different parameters of pavements. The subgrade moduli is also compared with the help of these machines. The falling weight deflectometer (FWD) was carried out on the plastic cell filled concrete block pavement (PCCBP), Geocell filled concrete concrete block pavement (GCCBP) and grouted macadam (GM). The deflection, modulus of elasticity, strain, thickness calculation, area, RRS were calculated through this test by the back calculation. From this observation it is found that the geocell filled concrete block pavement performed well as compared to the other pavements in terms of the calculated parameter. The deflection was more in the grouted macadam when compared with the PCCBP and GCCBP.
\end{abstract}

Keywords: Deflection, Strain, FWD, Thickness, Concrete Block Pavement

\section{Introduction}

The geocells are used for the pavement applications like the pavements subjected to repeated loadings. The observations included that the if the multiple gerocell reinforced section if used then it performed better as compared to the single geocell reinforced section [1-3]. The study was conducted on the geocell and the observations showed that the application of geocell is useful in the pavements, railways, reinforced wall, etc [4-6].

The dynamic response of the soil and subgrade is depending on the different parameters like frequency range of the excitation. The relevant condition for the performance of FWD on JPCP is very important to measure the deflection. The sonic method to measure the pavement deflection and temperature measurement is very good tool [7-9].

\section{Methodology}

Falling Weight Deflectometer (FWD) is an impulseloading device in which a transient load is applied to the pavement and the deflected shape of the pavement surface is measured. A falling weight deflectometer (FWD) is a testing device to evaluate the physical properties of pavement [1013]. FWD data is primarily used to estimate pavement structural capacity for overlay design also falling weight deflectometer (FWD) enables researchers to perform nondestructive, quick, and dynamic evaluations of paved surfaces, aggregate sub-bases, and soil subgrades without leaving the testing vehicle. The FWD is designed to impart a load pulse to the pavement surface which simulates the load produced by a rolling vehicle wheel [14-16]. The load is produced by dropping a large weight, and transmitted to the 
pavement through a circular load plate - typically $300 \mathrm{~mm}$ diameter on roads and $450 \mathrm{~mm}$ on airports. Typically, the load for road testing is about $40 \mathrm{kN}$ recommended by IRC 115 : 2014. The machine is usually contained within a trailer that can be towed to a location by another vehicle. It can also be built on a pickup truck, inside a mini-van or on a heavy truck together [17-18].

Different magnitudes of impulse load can be obtained by selection of a suitable mass and an appropriate height of fall. Under the application of the impulse load, the pavement deflects. Velocity transducers are placed on the pavement surface at different radial locations to measure surface deflections. Geophones or seismometers are used as displacement transducers. Load and deflection data are acquired with the help of a data acquisition system. Deflection sensors (geophones; force-balance seismometers) mounted radially from the center of the load plate measure the deformation of the pavement in response to the load. Some typical offsets are $0 \mathrm{~mm}, 200 \mathrm{~mm}, 300 \mathrm{~mm}, 450 \mathrm{~mm}$, $600 \mathrm{~mm}, 900 \mathrm{~mm}, 1200 \mathrm{~mm} 1500 \mathrm{~mm}$.

There are two different types of load impact systems; single-mass (e.g. Dynatest, Carl Bro, PaveTesting) and double-mass (KUAB). The testing machine used was double mass load impact system. The double-mass system produces a longer loading duration that more precisely represents a wheel load. The double-mass system has higher reproducibility and gives a more accurate result on pavements built on soft soils. The single-mass system may overestimate the capacity of pavements built on soft soils.

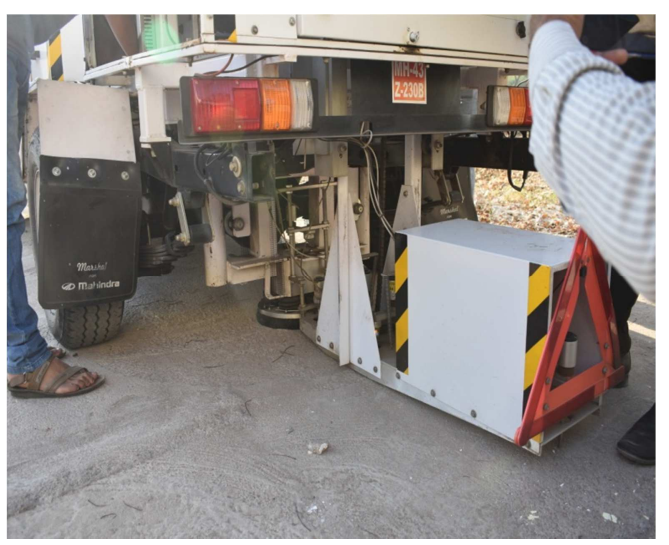

Figure 1. Falling Weight Deflectometer Machine Testing on the pavement.

\section{Results}

The requirement for rigid pavement actual test track is constructed with Sub base as flexible crust layer and top layer with concrete and geocells to be treated as rigid pavement crust layer. Normal FWD test is to be carried out at min. $150 \mathrm{~m}$. Being test constructed for research purpose to innovate various strength parameters, analysis is done with rigid and also with flexible pavement strength analysis. For this analysis three test points are located on test track and testing has been carried out for $60 \mathrm{KN}$ dynamic loads. In flexible analysis Pavement crust has been divided in two layers of each 2 Layers $7.5 \mathrm{~cm}$ concrete as rigid pavement and 2 layers of $25 \mathrm{~cm}$ of subbase as flexible pavement.

The data for PCCBP is as follows:

Table 1. Deflection and Lifetime for PCCBP.

\begin{tabular}{lll}
\hline Position & D0 & Lifetime (Years) \\
\hline M & $\boldsymbol{\mu m}$ & 20 \\
0 & 355 & 20 \\
4 & 424 & 20 \\
8 & 359 & 20 \\
\hline
\end{tabular}

Table 2. Back calculations for PCCBP.

\begin{tabular}{|c|c|c|c|c|c|c|c|}
\hline \multirow{2}{*}{ Layer } & Thickness & \multirow{2}{*}{ Poissons ratio } & \multirow{2}{*}{$\begin{array}{l}\text { Emax } \\
\text { Mpa }\end{array}$} & \multirow{2}{*}{$\begin{array}{l}\text { Emin } \\
\text { Mpa }\end{array}$} & \multirow{2}{*}{$\begin{array}{l}\text { Eseed } \\
\text { Мpa }\end{array}$} & \multirow{2}{*}{$\begin{array}{l}\text { Reference } \\
\mu \text {-strain }\end{array}$} & \multirow{2}{*}{ Kexponent } \\
\hline & $\mathbf{c m}$ & & & & & & \\
\hline 1 & 75 & 0.15 & 3000 & 1000 & 3000 & 195 & 5.62 \\
\hline 2 & 75 & 0.15 & 3000 & 50 & 3000 & 885 & 4 \\
\hline 3 & 250 & 0.15 & 500 & 50 & 500 & 885 & 4 \\
\hline 4 & 250 & 0.15 & 500 & 20 & 500 & 885 & 4 \\
\hline
\end{tabular}

The modulus of elasticity of different positions are obtained as follows:

Table 3. Modulus of Elasticity for PCCBP.

\begin{tabular}{|c|c|c|c|c|c|c|c|c|c|}
\hline Position & D0 & E0 & Ecor & Emod2 & Emod3 & Esub & HasfH5app & \multirow{2}{*}{ Critical } & Aoverla \\
\hline $\mathbf{M}$ & $\mu \mathbf{m}$ & Мра & Мра & Мра & Мра & $\mathbf{c m}$ & $\mathbf{C m}$ & & $\mathbf{c m}$ \\
\hline 0 & 355 & 1324 & 1000 & 58 & 50 & 20 & 75 & 1 & 0 \\
\hline 2 & 424 & 1253 & 1000 & 148 & 50 & 25 & 75 & 1 & 0 \\
\hline 4 & 359 & 1206 & 1000 & 149 & 50 & 25 & 75 & 1 & 0 \\
\hline 8 & 415 & 1193 & 1000 & 104 & 50 & 20 & 75 & 1 & 0 \\
\hline
\end{tabular}

The similar data of falling weight deflectometer is mentioned in the Annexure-B.

The strength parameters computerized analysis is as per the KUAB analysis by PVD software.

The deflection at different points is in the case of plastic cell filled concrete pavement obtained as follows: 


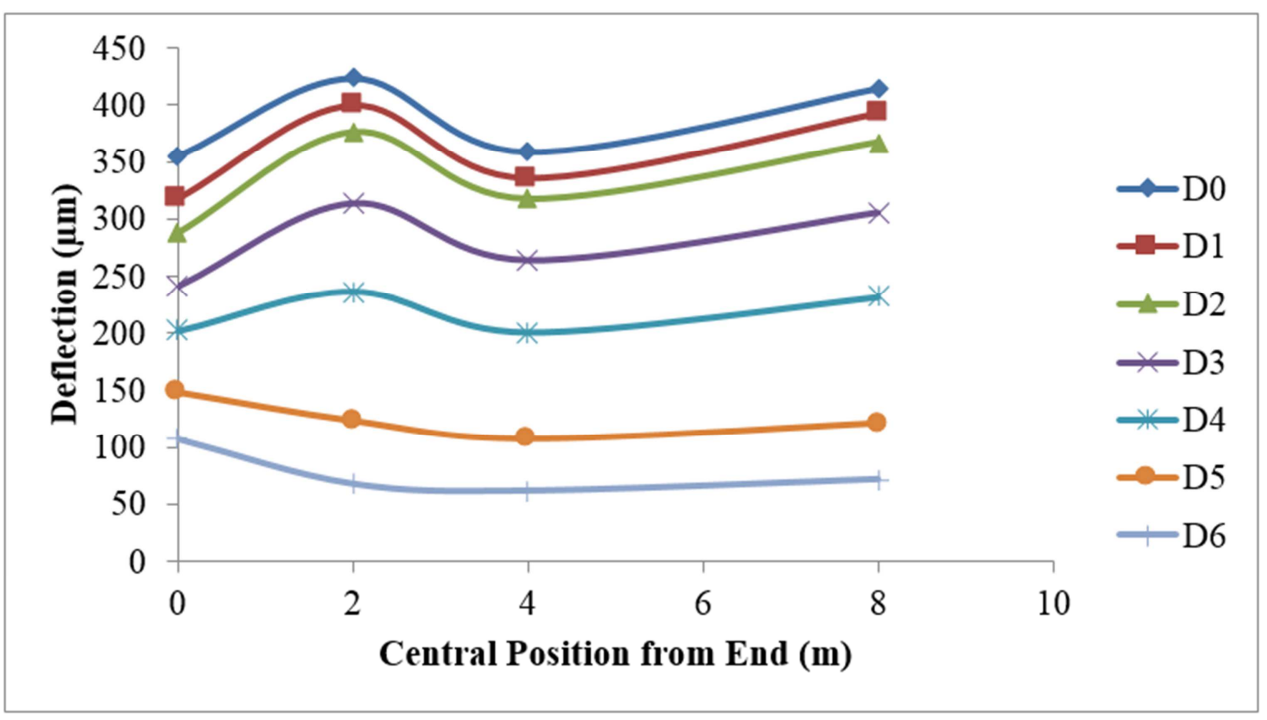

Figure 2. Deflection $v / s$ position of sensors.

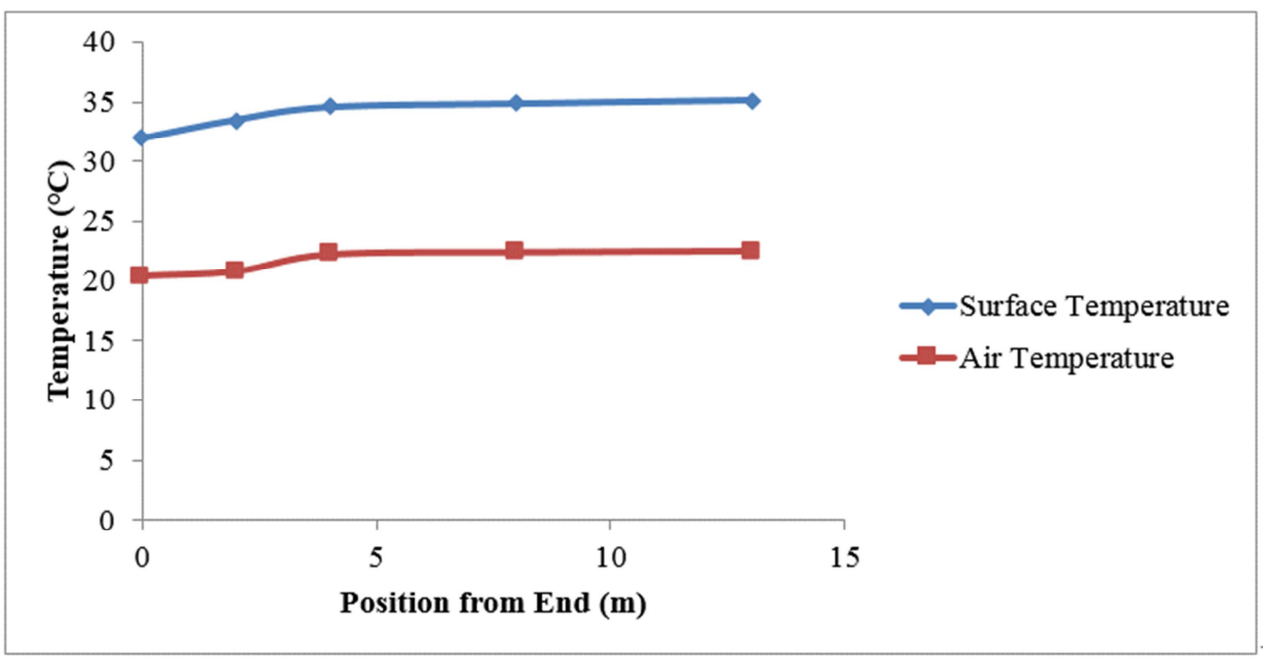

Figure 3. Temperature $v / s$ position of sensors.

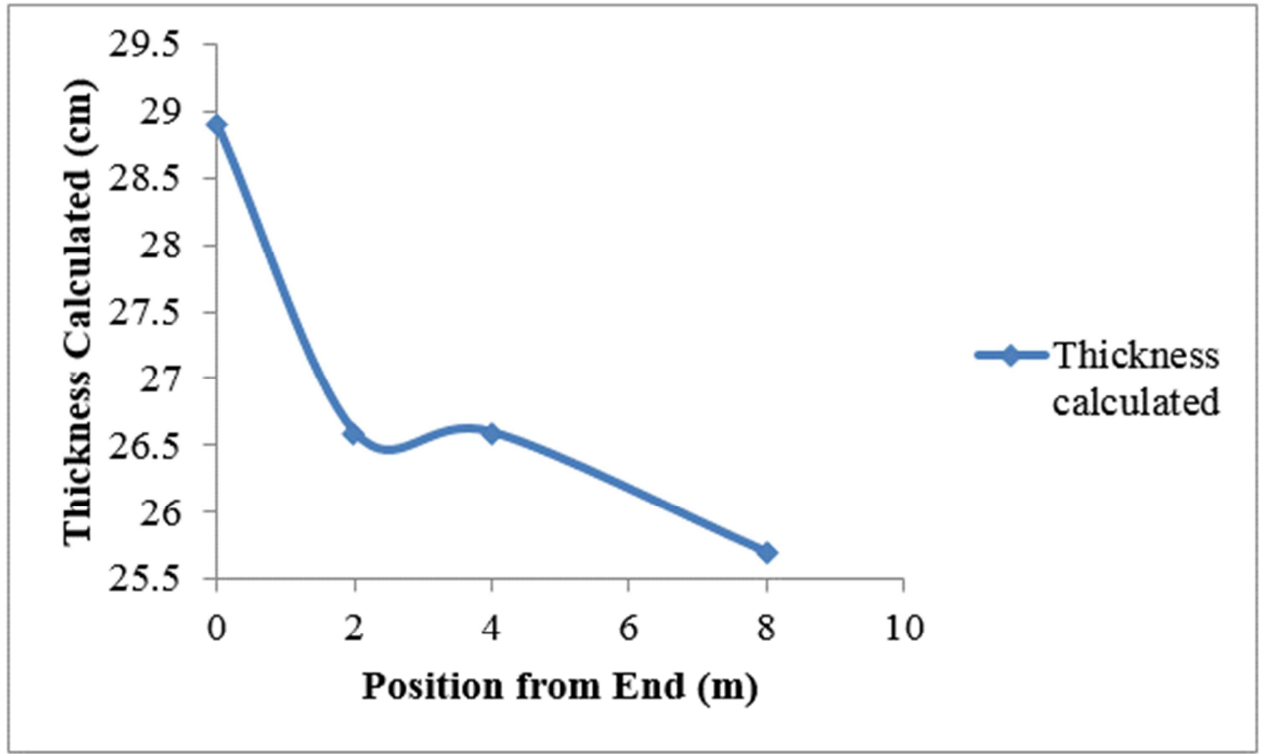

Figure 4. Thickness calculated (cm) v/s different position of sensors. 


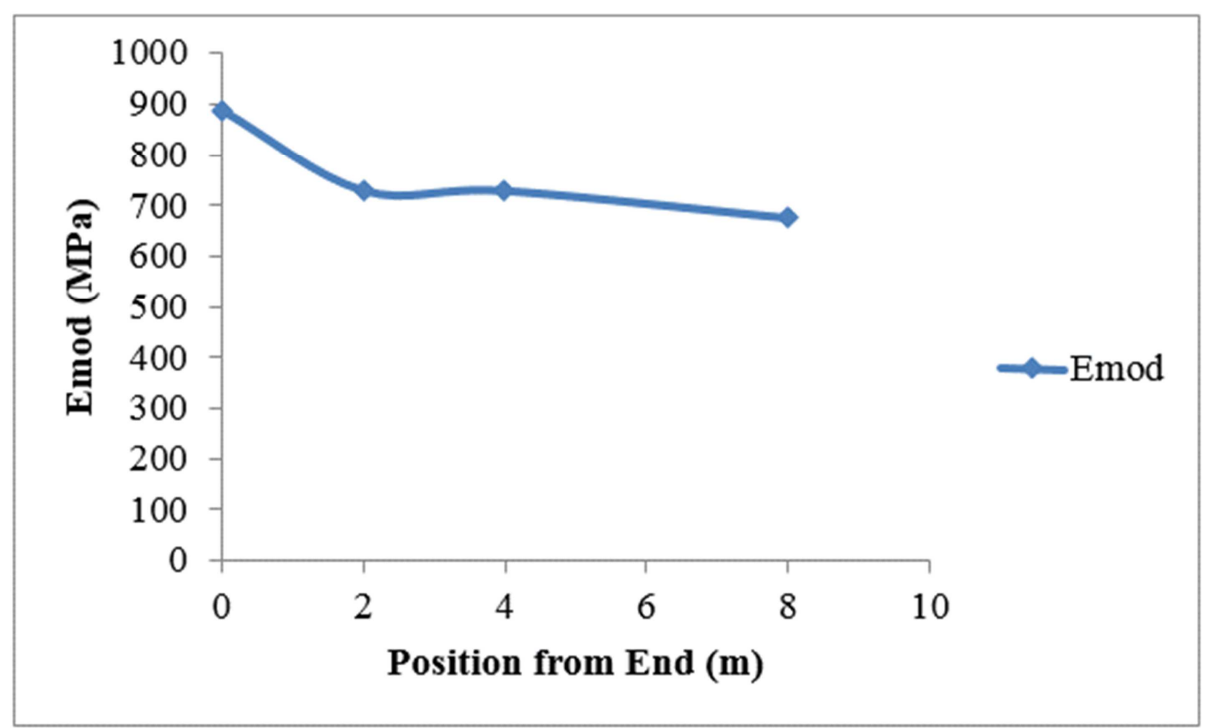

Figure 5. Modulus of elasticity $v /$ s position of sensors.

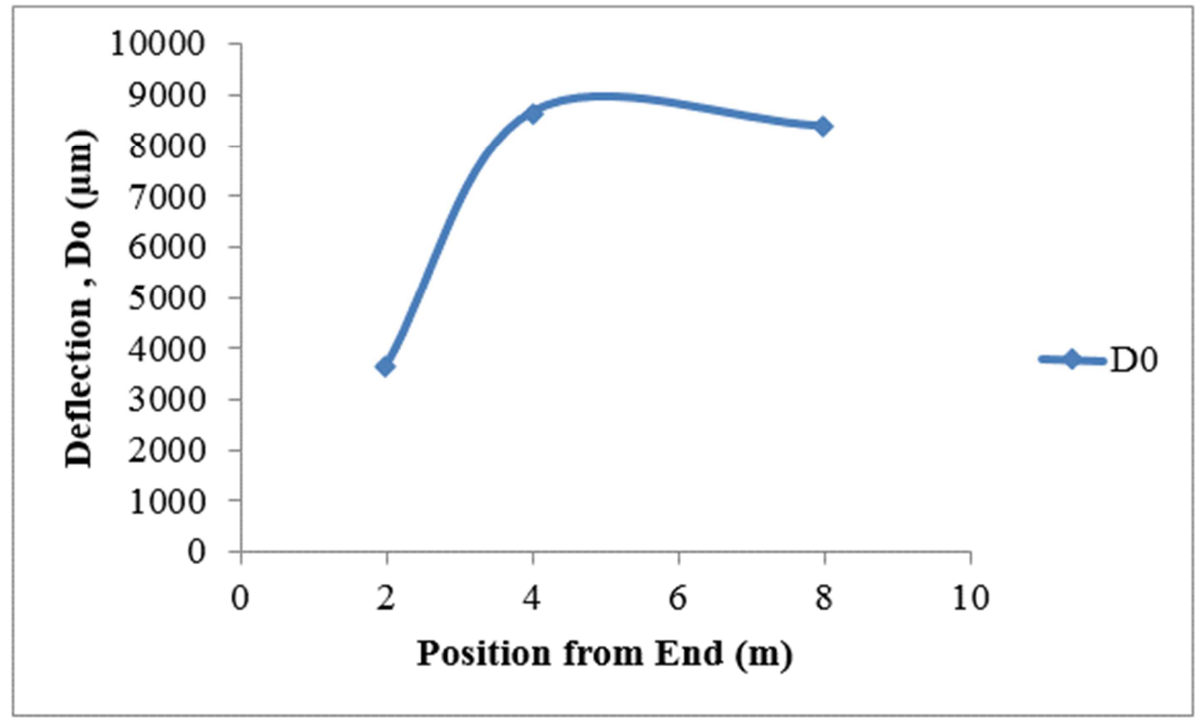

Figure 6. Deflection v/s position of sensors.

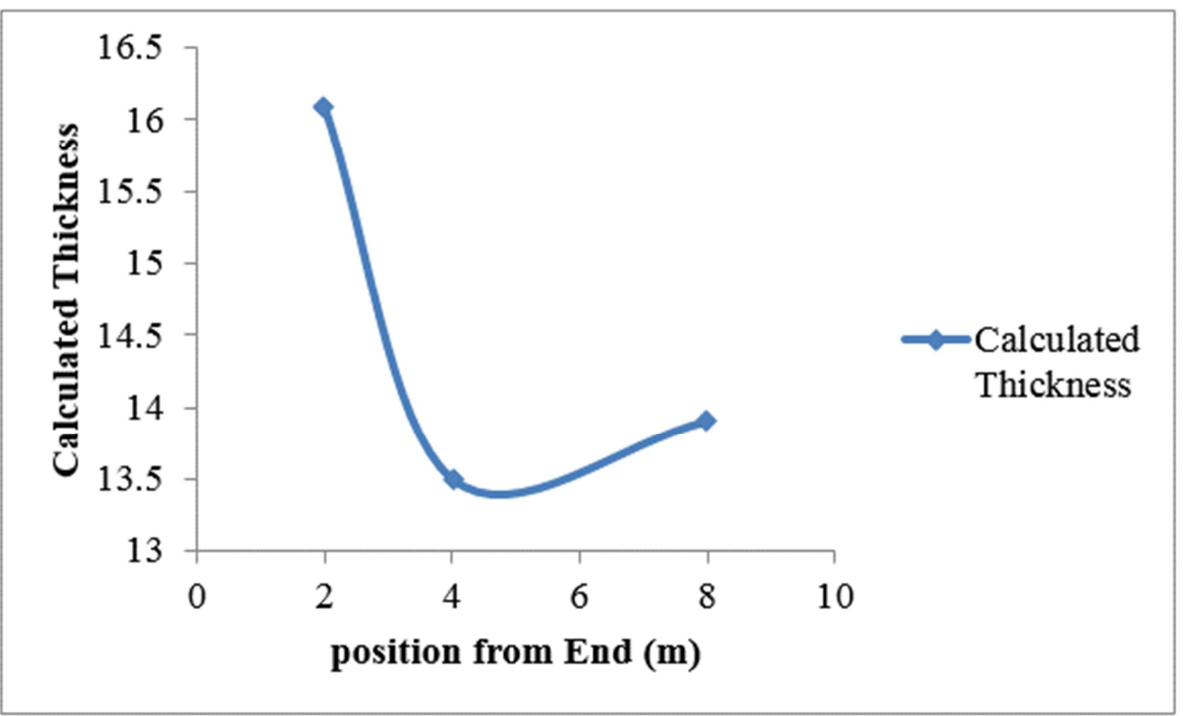

Figure 7. Calculated thickness (cm) v/s position of sensor. 
From the above diagram it is found that the sensors which are placed at the distance of $0.0 \mathrm{~cm}$ (D0), $20.0 \mathrm{~cm}$ (D1), $30.0 \mathrm{~cm}$ (D2), $45.0 \mathrm{~cm}$ (D3), $60.0 \mathrm{~cm}$ (D4), $90.0 \mathrm{~cm}$ (D5) and $120.0 \mathrm{~cm}$ (D6), the deflection is obtained through the sensors. It is found that the deflection is maximum in case of sensors placed at the first point.

Also, the temperature sensors placed in the machine and it has given the following results for the case of surface and air temperature.

From the above graph it is found that the surface temperature is more as compared to the air temperature since the readins are noted till the surface has absorbed sufficient heat.

The thickness is back calculated by the FWD and it has given following results for different points.

From the above graph it is observed that the thickness for the first four is higher as compared to the last point. The modulus of elasticity was calculated by FWD is shown in the following graph.
From the above graph it is observed that the Modulus of Elasticity observed to be higher for the first point as compared to the last point.

The deflection for the case of Grouted macadam is obtained in the following graph.

From the above graph it is observed that the deflection is higher for the last point. Since this is a grouted macadam the deflection as compared to the PCCBP is very large. This means that the PCCBP is stronger as compared to GM.

The back calculations were obtained from FWD for the case of GM is shown in the following graph.

The thickness is back calculated by the software of FWD and it is observed that the thickness is somewhere only $13.5 \mathrm{~cm}$ but the thickness was maintained as $15 \mathrm{~cm}$. Therefore it shows that the cement grout is not penetrated upto the full depth at certain locations.

The modulus of elasticity for the case GM is obtained as follows:

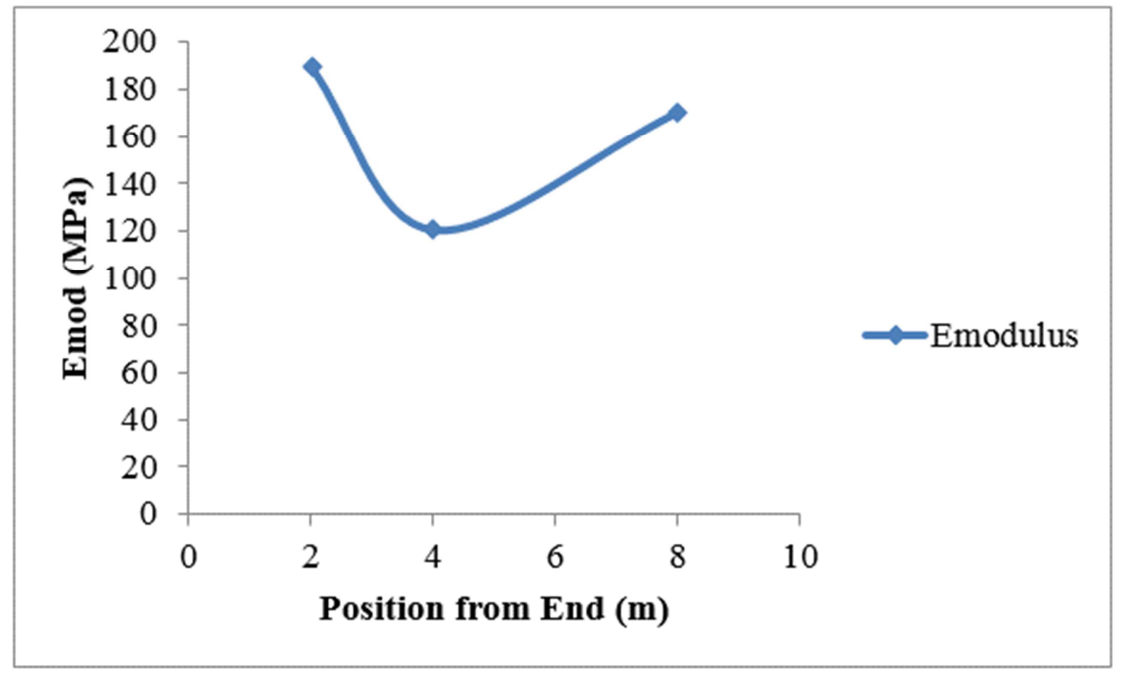

Figure 8. The Modulus of Elasticity $v /$ s position of sensors.

When compared with the PCCBP Emod is lesser and it showed that the PCCBP is stronger as compared to the GM.

When compared to the grouted macadam the PCCBP has given good results and therefore the further analysis of strain is carried out for the PCCBP. The Appendix shows the results for the other types of low volume roads.

\section{Conclusion}

The falling weight delflectometer (FWD) is good non destructive machine to know the parameters of pavement. The flexible, rigid and semi-rigid pavement behaves differently from each other. The semi-rigid pavement condition existed in the present research. From the above research papers it is found that the PCCBP and GFCBP gives good result in terms of the deflection, modulus of elasticity and strain when compared with grouted macadam. The lifetime period for this type of pavement is also high.

\section{Appendix}

a) Falling Weight Deflectometer (FWD) Analysis for Plastic Cell filled Concrete Block Pavement (PCCBP):

Table 4. Deflection for Sensor distance with positions for PCCBP

\begin{tabular}{|c|c|c|c|c|c|c|c|}
\hline Sensor distance $(\mathrm{cm})$ & $\mathbf{0}$ & 20 & 30 & 45 & 60 & 90 & 120 \\
\hline Position & D0 & D1 & D2 & D3 & D4 & D5 & D6 \\
\hline $\mathbf{M}$ & $\mu \mathrm{m}$ & $\mu \mathrm{m}$ & $\mu \mathrm{m}$ & $\mu \mathrm{m}$ & $\mu \mathrm{m}$ & $\mu \mathrm{m}$ & $\mu \mathrm{m}$ \\
\hline 0 & 355 & 318 & 287 & 241 & 202 & 148 & 107 \\
\hline 2 & 424 & 400 & 376 & 313 & 236 & 123 & 68 \\
\hline 4 & 359 & 336 & 317 & 264 & 201 & 107 & 62 \\
\hline 8 & 415 & 393 & 367 & 305 & 231 & 121 & 72 \\
\hline
\end{tabular}


Table 5. Temperature for the position of sensors for PCCBP.

\begin{tabular}{lll}
\hline Position & Surface Temperature & Air Temperature \\
\hline $\mathbf{m}$ & ${ }^{\circ} \mathbf{C}$ & ${ }^{\circ} \mathbf{C}$ \\
\hline 0 & 31.9 & 20.4 \\
2 & 33.5 & 20.8 \\
4 & 34.6 & 22.3 \\
8 & 34.9 & 22.5 \\
13 & 35.2 & 22.6 \\
\hline
\end{tabular}

Table 6. Input values for PCCBP.

\begin{tabular}{ll}
\hline Poisson's ratio & 0.15 \\
Joint transfer ratio (\%) & 80 \\
Axle Load (Ton) & 40 \\
Joint Distance & 7.5 \\
Slab temperature difference $\left({ }^{\circ} \mathrm{C}\right)$ & 30 \\
Slab E modulus (Mpa) & 32908 \\
Stress allowed in PCC-Centre $\left(\mathrm{Kgf} / \mathrm{cm}^{2}\right)$ & 30 \\
Stress allowed in PCC-Edge $\left(\mathrm{Kgf} / \mathrm{cm}^{2}\right)$ & 75 \\
Stress allowed in PCC-Corner $\left(\mathrm{Kgf} / \mathrm{cm}^{2}\right)$ & 100 \\
\hline
\end{tabular}

Table 7. Modulus of Elasticity for different positions of sensors for PCCBP.

\begin{tabular}{|c|c|c|c|c|c|c|}
\hline Position & D0 & Area & \multirow{2}{*}{ RRS } & \multirow{2}{*}{$\mathbf{k}$} & Thickness & Emod \\
\hline $\mathbf{m}$ & $\mu \mathrm{m}$ & $\mathbf{c m}^{2}$ & & & $\mathbf{c m}$ & Мpa \\
\hline 0 & 358 & 27 & 60 & 5 & 28.9 & 888 \\
\hline 2 & 355 & 25 & 51 & 7 & 26.6 & 729 \\
\hline 4 & 358 & 25 & 51 & 6 & 26.6 & 728 \\
\hline 8 & 418 & 25 & 51 & 6 & 25.7 & 675 \\
\hline
\end{tabular}

b) FWD Track: Cement Grouted Macadam (CGM):

Table 8. Deflection for sensor distances with positions for CGM.

\begin{tabular}{|c|c|c|c|c|c|c|c|}
\hline Sensor distance $(\mathrm{cm})$ & $\mathbf{0}$ & 20 & 30 & 45 & 60 & 90 & 120 \\
\hline Position & D0 & D1 & D2 & D3 & D4 & D5 & D6 \\
\hline $\mathbf{m}$ & $\mu \mathrm{m}$ & $\mu \mathrm{m}$ & $\mu \mathrm{m}$ & $\mu \mathrm{m}$ & $\mu \mathrm{m}$ & $\mu \mathrm{m}$ & $\mu \mathrm{m}$ \\
\hline 2 & 3666 & 1195 & 325 & 16 & 2 & 89 & 68 \\
\hline 4 & 8658 & 4409 & 344 & 4 & 0 & 36 & 27 \\
\hline 8 & 8378 & 1829 & 376 & 13 & -1 & 15 & 15 \\
\hline
\end{tabular}

Table 9. Temperature for positions of sensors in CGM.

\begin{tabular}{lll}
\hline Position & Surface Temperature & Air Temperature \\
\hline $\mathbf{m}$ & ${ }^{\circ} \mathbf{C}$ & ${ }^{\circ} \mathbf{C}$ \\
\hline 2 & 36.8 & 23.1 \\
4 & 35.3 & 22.8 \\
8 & 35.6 & 22.6 \\
\hline
\end{tabular}

Table 10. Input values for CGM.

\begin{tabular}{ll}
\hline Poisson's ratio & 0.15 \\
Joint transfer ratio (\%) & 80 \\
Axle Load (Ton) & 40 \\
Joint Distance & 7.5 \\
Slab temperature difference $\left({ }^{\circ} \mathrm{C}\right)$ & 30 \\
Slab E modulus (Mpa) & 30000 \\
Stress allowed in PCC-Centre $\left(\mathrm{Kgf} / \mathrm{cm}^{2}\right)$ & 27 \\
Stress allowed in PCC-Edge $\left(\mathrm{Kgf} / \mathrm{cm}^{2}\right)$ & 75 \\
Stress allowed in PCC-Corner $\left(\mathrm{Kgf} / \mathrm{cm}^{2}\right)$ & 100 \\
\hline
\end{tabular}

Table 11. Modulus of elasticity for CGM.

\begin{tabular}{|c|c|c|c|c|c|c|}
\hline Position & D0 & Area & \multirow{2}{*}{ RRS } & \multirow{2}{*}{$\mathbf{k}$} & Thickness & Emod \\
\hline m & $\mu \mathrm{m}$ & $\mathrm{cm}^{2}$ & & & $\mathbf{c m}$ & Мра \\
\hline 2 & 3666 & 18 & 33 & 3 & 16.1 & 189 \\
\hline 4 & 8658 & 17 & 32 & 1 & 13.5 & 120 \\
\hline 8 & 8378 & 17 & 32 & 2 & 13.9 & 170 \\
\hline
\end{tabular}


c) FWD Analysis for Geocell filled concrete block pavement (GFCBP):

Table 12. Deflection for the position of sensors in Geocell filled concrete block pavement.

\begin{tabular}{llllllll}
\hline Sensor distance (cm) & $\mathbf{0}$ & $\mathbf{2 0}$ & $\mathbf{3 0}$ & $\mathbf{4 5}$ & $\mathbf{6 0}$ & $\mathbf{9 0}$ & $\mathbf{1 2 0}$ \\
\hline Position & $\mathbf{D 0}$ & $\mathbf{D 1}$ & $\mathbf{D 2}$ & $\mathbf{D 3}$ & $\mathbf{D 4}$ & $\mathbf{D 5}$ & $\mathbf{D 6}$ \\
\hline $\mathbf{m}$ & $\boldsymbol{\mu m}$ & $\boldsymbol{\mu m}$ & $\boldsymbol{\mu m}$ & $\boldsymbol{\mu m}$ & $\boldsymbol{\mu m}$ & $\boldsymbol{\mu m}$ & $\boldsymbol{\mu m}$ \\
\hline 0 & 355 & 318 & 287 & 241 & 202 & 148 & 107 \\
2 & 424 & 400 & 376 & 313 & 236 & 23 & 68 \\
4 & 359 & 336 & 317 & 264 & 201 & 107 & 62 \\
8 & 415 & 393 & 367 & 305 & 231 & 121 & 72 \\
\hline
\end{tabular}

Table 13. Temperature for the position of sensors in Geocell filled concrete block pavement.

\begin{tabular}{lll}
\hline Position & Surface Temperature & Air Temperature \\
\hline $\mathbf{m}$ & ${ }^{\circ} \mathbf{C}$ & ${ }^{\circ} \mathbf{C}$ \\
\hline 0 & 31.9 & 20.4 \\
2 & 33.5 & 20.8 \\
4 & 34.6 & 22.3 \\
8 & 34.9 & 22.5 \\
13 & 35.2 & 22.6 \\
\hline
\end{tabular}

Table 14. Input values for Geocell filled concrete block pavement.

\begin{tabular}{ll}
\hline Number of loads per day & 200 \\
Growth in number of loads per Year (\%) & 5 \\
Design lifetime for section (years) & 10 \\
modulus for asphalt overlay (E) -Mpa & 5000 \\
Poissons ratio for asphalt overlay & 0.35 \\
Reference temperature for calculations & $40^{\circ} \mathrm{C}$ \\
\hline
\end{tabular}

Table 15. Modulus of Elasticity for Geocell filled concrete block pavement.

\begin{tabular}{llllllll}
\hline \multirow{2}{*}{ Layer } & Thickness & \multirow{2}{*}{ Poissons ratio } & Emax & Emin & Eseed & \multicolumn{2}{c}{ Reference } \\
\cline { 2 - 6 } & $\mathbf{c m}$ & & Mpa & Mpa & Mpa & $\boldsymbol{\mu}$-strain & \multicolumn{2}{c}{ Kexponent } \\
\hline 1 & 75 & 0.15 & 3000 & 1000 & 3000 & 195 & 5.62 \\
2 & 75 & 0.15 & 3000 & 50 & 3000 & 885 & 4 \\
3 & 250 & 0.15 & 500 & 50 & 500 & 885 & 4 \\
4 & 250 & 0.15 & 500 & 20 & 500 & 885 & 4 \\
\hline
\end{tabular}

\section{Nomenclature}

$\begin{array}{ll}\text { PCCBP } & \text { Plastic Cell filled Concrete Block Pavement } \\ \text { GFCBP } & \text { Geocell Filled Concrete Block Pavement } \\ \text { CGM } & \text { Cement Grouted Macadam } \\ \text { CGBM } & \text { Cement Grouted Bituminous Macadam } \\ \text { E0 } & \text { E modulus of layer 1, at the temperature of the measurement, calculated value } \\ \text { E } & \text { E modulus of layer 1, at the temperature of the measurement, calculated value } \\ \text { Ecorr } & \text { E modulus of layer 1, after temperature correction, calculated value } \\ \text { Emod2 } & \text { E modulus of layer 2, calculated value } \\ \text { Emod3 } & \text { E modulus of layer 3, calculated value } \\ \text { Emod4 } & \text { E modulus of layer 4, calculated value } \\ \text { RRS } & \text { Radius of Relative Stiffness } \\ \text { Esub } & \text { The E modulus of the subgrade, calculated value } \\ \text { Hasf } & \text { The thickness of the asphalt layer, before overlay, user input } \\ \text { Ecorr } & \text { E modulus of layer 1, after temperature correction, calculated value } \\ \text { Esub } & \text { The E modulus of the subgrade, calculated value } \\ \text { Hasf } & \text { The thickness of the asphalt layer, before overlay, user input } \\ \text { Critical layer } & \text { Critical layer, the layer with the shortest lifetime } \\ \text { A overlay } & \text { The overlay necessary to reach the requested life time, calculated value } \\ \text { Lifetime } & \text { Life time for the existing structure, calculated value Poisson Ratio-The Poisson ratio for the layer }\end{array}$


The maximum possible value of E modulus that the layer might have, at reference temperature, If the
modulus reaches this value in the iteration process it is not further increased
The minimum possible value of E modulus that the layer might have, at reference temperature, If the
modulus reaches this value in the iteration process it is not further deceased
Emin
The most likely value of E modulus that the layer will have
Reference strain

\section{References}

[1] Andrzej, M. \& Marta, M., 2014. Modern NDT Systems for Structural Integrity Examination of Concrete Bridge Structures. Procedia Engineering, Volume 91, pp. 418-423.

[2] Anon., 1997. Nondestructive evaluation of concrete with impact-echo and pulse- velocity techniques: 47640 Limaye, H. S.; Krause, R. J. Materials Evaluation, Vol. 49, No. 10, pp. 1312-1315 (Oct. 1991). NDT \& E International, Volume 30, pp. 262-263.

[3] Asli, C., Feng, Z.-Q., Porcher, G. \& Rincent, J.-J., 2012. Back-calculation of elastic modulus of soil and subgrade from portable falling weight deflectometer measurements. Engineering Structures, Volume 34, pp. 1-7.

[4] Březina, I., Grošek, J. \& Janků, M., 2017. Measurement of Deflections and Determination of Jointed Plain Concrete Pavements Stiffness by Falling Weight Deflectometer. Procedia Engineering, Volume 190, pp. 162-169.

[5] Davis, A. G., 2003. The nondestructive impulse response test in North America: 1985-2001. NDT \& E International, Volume 36, pp. 185-193.

[6] Edwards, L. \& Bell, H. P., 2016. Comparative evaluation of nondestructive devices for measuring pavement thickness in the field. International Journal of Pavement Research and Technology, Volume 9, pp. 102-111.

[7] Gosk, W., 2016. Stiffness Estimation of the Soil Built-in Road Embankment on the Basis of Light Falling Weight Deflectometer Test. Procedia Engineering, Volume 143, pp. 395-402.

[8] Guzzarlapudi, S. D., Adigopula, V. K. \& Kumar, R., 2016. Comparative studies of lightweight deflectometer and Benkelman beam deflectometer in low volume roads. Journal of Traffic and Transportation Engineering (English Edition), Volume 3, pp. 438-447.

[9] Hegde, A., 2017. Geocell reinforced foundation beds-past

findings, present trends and future prospects: A state-of-the-art review. Construction and Building Materials, Volume 154, pp. 658-674.

[10] Lam, M. N.-T., Jaritngam, S. \& Le, D.-H., 2017. Rollercompacted concrete pavement made of Electric Arc Furnace slag aggregate: Mix design and mechanical properties. Construction and Building Materials, Volume 154, pp. 482495.

[11] Nega, A., Nikraz, H. \& Al-Qadi, I. L., 2016. Dynamic analysis of falling weight deflectometer. Journal of Traffic and Transportation Engineering (English Edition), Volume 3, pp. 427-437.

[12] Pokharel, S. K., Han, J., Leshchinsky, D. \& Parsons, R. L., 2017. Experimental evaluation of geocell-reinforced bases under repeated loading. International Journal of Pavement Research and Technology.

[13] Rehman, S. K. U., Ibrahim, Z., Memon, S. A. \& Jameel, M., 2016. Nondestructive test methods for concrete bridges: A review. Construction and Building Materials, Volume 107, pp. 58-86.

[14] Ruta, P., Krawczyk, B. \& Szydło, A., 2015. Identification of pavement elastic moduli by means of impact test. Engineering Structures, Volume 100, pp. 201-211.

[15] Sack, D. A. \& Olson, L. D., 1995. Advanced NDT methods for evaluating concrete bridges and other structures. NDT \& E International, Volume 28, pp. 349-357.

[16] Sirithepmontree, H. \& Sapsathiarn, Y., 2017. Dynamic Soil Models for Backcalculation of Material Properties from Falling Weight Deflectometer Deflection Data. Procedia Engineering, Volume 189, pp. 152-157.

[17] Suku, L., Prabhu, S. S., Ramesh, P. \& Babu, G. L. S., 2016. Behavior of geocell-reinforced granular base under repeated loading. Transportation Geotechnics, Volume 9, pp. 17-30.

[18] Thakur, J. K., Han, J., Pokharel, S. K. \& Parsons, R. L., 2012. Performance of geocell-reinforced recycled asphalt pavement (RAP) bases over weak subgrade under cyclic plate loading. Geotextiles and Geomembranes, Volume 35, pp. 14-24. 